\title{
MORPHOLOGICAL AND DIMENSIONAL PROPERTIES OF UNMODIFIED AND MODIFIED BRAILLE DOTS PRODUCED WITH UV INKJET PRINTING
}

\section{MORFOLOŠKE IN DIMENZIJSKE LASTNOSTI NEMODIFICIRANE IN MODIFICIRANE BRAJICE IZDELANE Z UV KAPLJIČNIM TISKOM}

\author{
Bojan Rotar¹, Urška Stanković Elesini' ${ }^{1}$, Peter Hajdu² ${ }^{2}$ Blaž Leskovar³ \\ Raša Urbas $^{1 *}$ \\ ${ }^{1}$ Chair of Information and Graphic Arts Technology, Faculty of Natural Sciences and Engineering, University of Ljubljana, \\ Aškerčeva 12, 1000 Ljubljana, Slovenia \\ ${ }^{2}$ Grec d. o. o., Cesta Andreja Bitenca 68, 1000 Ljubljana, Slovenia \\ ${ }^{3}$ Department of Materials and Metallurgy, Faculty of Natural Sciences and Engineering, University of Ljubljana, \\ Aškerčeva 12, 1000 Ljubljana, Slovenia \\ Prejem rokopisa - received: 2020-01-27; sprejem za objavo - accepted for publication: 2020-09-01
}

doi: $10.17222 /$ mit.2020.016

Texts in braille are longer than texts in Latin, and so some modifications have taken place over the years, most referring to the contractions of words, with fewer focusing on the possibilities offered by newer printing techniques. In the research, the braille dot was modified, printed with a UV inkjet technique and analysed. The modified braille dot was composed of the basic (unmodified) dot with an additional element printed on its top. The research was focused on the surface and structure morphology, and the dimensional changes of the dots printed with clear, acrylate-based UV ink. According to the SEM images, the surfaces of the unmodified and modified dots were smooth and regular. The spreading of the clear UV ink was reduced with a pre-printed layer of black acrylate-based UV ink on the surface of cardboard, which consequently increased the surface tension. The cracking of the clear UV ink was observed to a smaller extent at the base of the dot. The clear UV ink polymerised in a ridge pattern typical of an amorphous polymer microstructure. The dot dimensions changed compared to the preformulated dimensions. An obvious shrinkage of dots during curing was determined by measuring the diameter and area; however, an increase in the perimeter applied to the uneven dot boundary as a consequence of the slight spreading of the clear UV ink. The height of the basic dot was reduced for the modified dots due to a slight "collapse" of the layers, probably resulting from a small fraction of uncured UV ink, a dark substrate etc., as illustrated in the article.

Keywords: UV inkjet printing, curing, braille dot, dimensional changes

Besedila zapisana v brajici so daljša kot besedila v latinici, zato se je v zadnjih letih pojavilo nekaj modifikacij, ki so se večinoma nanašale na krajše zapise besed, manj pa jih je bilo osredotočenih na možnosti, ki jih omogočajo sodobnejše tehnike tiska. V pričujoči raziskavi smo modificirali brajevo piko, natisnjeno z UV kapljičnim tiskom, in jo analizirali. Modificirana pika je bila sestavljena iz osnovne (nemodificirane) pike $\mathrm{z}$ dotisnjenim dodatnim elementom na njenem vrhu. V raziskavi smo preučevali površinske in strukturne morfološke lastnosti ter dimenzijske spremembe pik, natisnjenih s prozornim UV črnilom na osnovi akrilata. Iz SEM-posnetkov je bilo ugotovljeno, da je bila površina nemodificiranih in modificiranih pik gladka in pravilne oblike. Razlivanje prozornega UV črnila se je zmanjšalo s predhodnim potiskom plasti črnega UV akrilatnega črnila na površino kartona, kar je posledično zvišalo površinsko napetost. Pokanje prozornega UV črnila je bilo opaziti v manjšem obsegu na tanjši plasti ob robu pike. Prozorno UV črnilo je polimeriziralo v valovitem vzorcu, tipičnem za mikrostrukturo amorfnih polimerov. Dimenzije pik so se spremenile v primerjavi z izhodiščnimi. Očitno skrčenje pik med strjevanjem (polimerizacijo) je bilo določeno z merjenjem premera in površine. Povečan obseg pike je posledica neenakomernosti robov pik, nastalih zaradi rahlega razlivanja prozornega UV črnila. Kot je razvidno iz prispevka, se je višina osnovnih pik, v primerjavi z modificiranimim, zmanjšala zaradi rahlega sesedanja plasti. Vzrokov za to je lahko več, in kot je navedeno v prispevku, smo jih iskali v možnem deležu nepolimeriziranega UV črnila, v črni podlagi itd.

Ključne besede: UV-kapljični tisk, strjevanje, braillova pika, dimenzijske spremembe

\section{INTRODUCTION}

According to the International Council on English Braille (ICEB) and The Rules of Unified English Braille, ${ }^{1}$ braille is defined as a tactile method of reading and writing for blind people. Digital technology has made braille more accessible for its users (e.g., with braille notetakers, transcription software, refreshable braille displays for computers etc.). However, the Royal

*Corresponding author's e-mail:

rasa.urbas@ntf.uni-lj.si (Raša Urbas)
Blind organisation emphasises that reading printed braille still remains important, as it allows users to learn spelling, punctuation and gain an understanding of how a text is formatted on a page. Therefore, printed texts in braille are still desirable and valuable for the visually impaired and blind.

Braille text can be printed with different techniques, e.g. embossing, ${ }^{2,3}$ thermo-vacuum technique (mainly used to produce tactile diagrams, figures etc.), screen printing, ${ }^{4,5} \mathrm{UV}$ inkjet and 3D printing. 5,6 
Compared to other techniques, a lot of attention has been given to UV inkjet printing in the last decade. It is used in various fields, such as the coating industry (anti-static, flame-retardant, dental industry, metal and textile coatings, etc.), graphics (also for braille printing) and microelectronics (display switches and drivers, e-paper, smart labels, radio-frequency identification tags (RFID), sensors etc.). ${ }^{7-10} \mathrm{UV}$ inkjet printing uses UV-curable inks, cured in a few seconds or minutes at room temperature, thus reducing the overall energy consumption, which are applicable to various materials (paper, textile, wood, glass, etc.). Yang et al. ${ }^{11}$ noted that different materials also have different requirements. It is therefore important to adjust the surface tension and viscosity of the ink to improve the printability. MendesFelipe et al. ${ }^{12}$ suggested that problems such as the bad adhesion of ink to the substrate, deformations, cracks or pores in printed elements or even incompletely cured materials could be reduced by optimizing the printing parameters and conditions (temperature, humidity etc.), surface treatments or modifying the design of printing elements.

Various researchers have been focusing on the problem of the volume shrinkage of photopolymers (cured materials). UV ink is composed of a photo-initiator, oligomers (forming the basic structure of the polymer network) or prepolymers, and monomers (acting as a reactive diluent to adjust the system viscosity). When the photo-initiator is exposed to UV light, it generates free radicals and initiates UV curing (crosslinking) until all the oligomers and monomers are crosslinked, forming a three-dimensional polymer structure. Park et al. ${ }^{13}$ highlighted that the volume shrinkage in acrylate and methacrylate systems occurs during the polymerisation. The weak and long Van der Waals interactions are replaced by shorter covalent bonds between carbon atoms of different monomer units. In another research, Park et al. ${ }^{9}$ concluded that the free volume of three-dimensional polymer structures is smaller than the free volume of molecules involved, which means that cured ink has a smaller volume than ink in the liquid state, which is reflected in the shrinkage of the material. K. Koseki et al. ${ }^{14}$ stated that the shrinkage of acrylate compounds has a reciprocal correlation with the molecular weight and when the cured system includes oligomers (mixed system), the time lag between the polymerisation reaction and the shrinkage behaviour occurs. Volume shrinkage causes aesthetic problems (deformation of the cured material shape) and reduces its adhesion to the surface..$^{914} \mathrm{~J}$. W. Park et al. ${ }^{13}$ emphasised that the shrinkage of the polymer depends on some variables (i.e., photo-initiator content, UV light intensity, environmental temperature) that must be controlled during curing.

As already mentioned, UV ink-jet printing is inter alia used for printing braille, since it is possible to use various materials for substrates (a well-known example is the metal buttons with braille inscription in elevators; they can be embossed but also printed with the UV ink-jet technique). G. Golob et al. ${ }^{15}$ showed that the technology of UV inkjet printing enables precise printing of even the smallest elements, which can be printed in one or more layers. In their research, a horizontal and vertical line, triangle and square were printed on the top of the braille dot. The basic braille dots and added elements were printed using five basic varnish layers. As shown in the research, blind people recognised and distinguished some shapes of added elements; however, not all, as shown in the research by Urbas et al. ${ }^{16}$ In the latter research, the added elements in the shape of a small dot and vertical line printed on a basic braille dot with the UV inkjet technique were the most recognisable elements for the blind. The possibility of upgrading dots opens up new possibilities for modifying braille writing, as explained in the continuation. In standardised braille, an additional character is used as an indicator for capital letters, as shown in Figure 1a. This indicator was, in the research, avoided by using modified braille dots instead of classic ones (hereinafter unmodified dots), as shown in Figure 1b. The term modified braille thus refers to the use of characters that are composed of base dots with an

\section{a)}

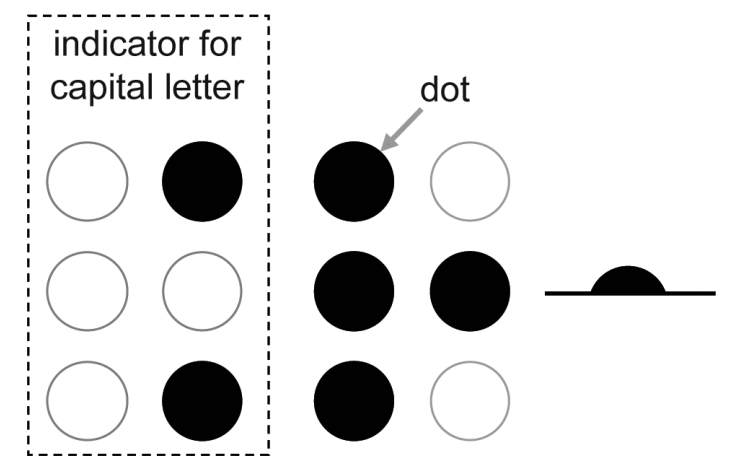

Letter $\mathrm{R}$ written with unmodified dots

b)

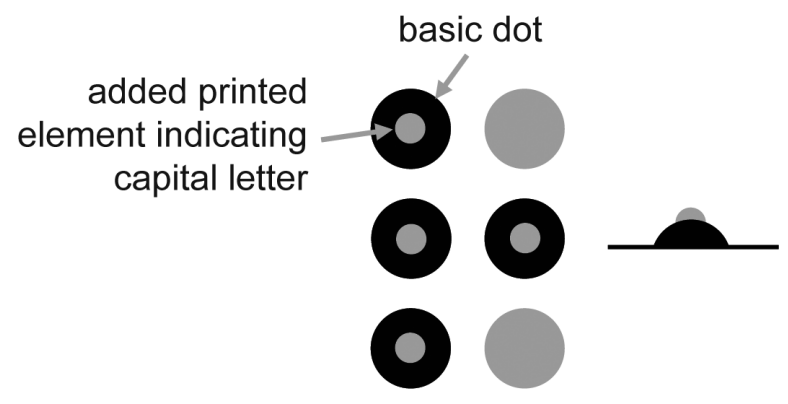

Letter $\mathrm{R}$ written with modified dots

Figure 1: Letter $\mathrm{R}$ written with a) unmodified and b) modified braille dots; two columns of three dots represent a braille cell; white dots represent unoccupied and unprinted places in the braille cell, while black dots are occupied, printed and tactile; grey dots are added elements printed on top of the basic dots in modified braille dots. 
additional element printed on the top of them (hereinafter modified dots).

By including modified dots into braille, the number of braille cells that need to be scanned with fingers can be reduced and the length of braille texts shortened. In this paper, a more extensive research of the structure and dimensions of modified braille dots in comparison to unmodified dots is presented. For that purpose, a new set of unmodified and modified braille dots was printed with the UV inkjet printing technique. The analysis was performed on a printing substrate before and after the pre-printing with a black UV ink, as well as on unmodified and modified braille dots printed with a clear UV ink. The surface and structure morphology were studied with a stereo microscope and scanning electron microscope. The measurements of dots were performed using the ImageJ program on captured images.

\section{EXPERIMENTAL PART}

\subsection{Materials}

For the purpose of the research, a prepared text was first translated into braille. The Marburg Medium font was used as a standard, recommending that the braille dot diameter be within the range of $1.3-1.6 \mathrm{~mm}$ and the height of up to $0.2 \mathrm{~mm}$. The text translation to braille was made by a computer program converting the text with the PharmaBraille SI font. When the text in braille was ready, appropriate layouts for inkjet printing were prepared in the Adobe Illustrator program. Each unmodified braille dot was composed of three layers. The diameter of the braille dot circle in each layer was different, gradually reducing; thus, for each layer, a separate layout was prepared. The first printed layer of a dot had the largest diameter (i.e., $1.586 \mathrm{~mm}$ ) and the third layer the smallest. In this way, the rounded shape of the braille dot was obtained. In the case of modified braille dots, the basic dot was first printed in three layers (the same as in unmodified dots), while an additional three layers were printed to get the smaller added element on the top of the basic dot. The same as in the basic dot, the first layer of the added element had the largest diameter (i.e., 0.500 $\mathrm{mm}$ ), while the other two added layers had their diameter gradually reduced.

After the layouts were prepared, the text in unmodified and modified braille was printed with a Roland DG LEC-330 piezoelectric UV inkjet printer (Roland DG Corporation, Japan) with a dual UV-LED lamp, with a printing resolution of $720 \mathrm{dpi} \times 1440 \mathrm{dpi}$. The printing was performed at room temperature (approx. $21^{\circ} \mathrm{C}$ ) and $65 \%$ relative humidity. With one passage of the substrate through the printing machine, one layer of braille dots was printed and cured.

The cardboard Kromopak (Količevo Karton d. o. o., Slovenia), with declared grammage of $275 \mathrm{~g} / \mathrm{m}^{2}$, was used as the printing substrate. The cardboard was preliminary pre-printed with one layer of acrylate-based black
EUV4-5BK printing ink (Roland DG Corporation, Japan) (hereinafter black UV ink). Braille dots were finally printed with acrylate-based clear EUV4-5GL ink (Roland DG Corporation, Japan) (hereinafter clear UV ink) onto the cardboard surface pre-printed with black UV ink. In both inks, 2,4,6-trimethylbenzoyldiphenylphosphine oxide (TPO) was used as the photo-initiator, which is used especially in thicker coatings. According to the technical data for the composition of commercial black and clear ink, it was assumed that the curing was proceeded as a free-radical chain polymerisation. The layer of black ink and the first layer of dots were cured under both lamps, while the other layers of dots were cured under the light of one lamp. The intensity of light in both lamps was constant while printing.

\subsection{Methods}

The properties of the unprinted and pre-printed cardboard were determined with different methods. The grammage $\left(\mathrm{g} / \mathrm{m}^{2}\right)$ was determined by weighing samples according to the standard SIST EN ISO 536:2012. The thickness $(\mathrm{mm})$ was measured with a Mitutoyo digital micrometre (Mitutoyo Corporation, Japan; measuring range $0-25 \mathrm{~mm}$, with accuracy $\pm 1 \mu \mathrm{m}$ ) according to the standard EN ISO 534:2012. The roughness ( $\mathrm{mL} / \mathrm{min})$ was measured on samples in accordance with the standard ISO 5636-3:1992. The capillary rise $(\mathrm{mm})$ is a test of the water-absorbing capacity of a material and was measured according to the Klemm method (standard ISO $8787: 1986)$. The resistance to bending $(\mathrm{N})$ was measured according to the standard ISO 2493-2:2011 on a dynamometer INSTRON mod. 5567 (Instron Ltd., USA) and was recorded as the force needed to bend a sample by $15^{\circ}$ at a bending length of $50 \mathrm{~mm}$. The surface tension $\left(\mathrm{mJ} / \mathrm{m}^{2}\right)$ was determined by measuring the contact angles on a Dynamic Absorption Tester DAT 1100 (Fibro system, Sweden) according to the standardised method TAPPI T558.

The study of shape and dimensions of braille dots was performed with the use of a Leica S9i stereo microscope (Leica Microsystems Ltd., Germany) and the Java-based image-processing program ImageJ (NIH, USA). The images of five unmodified and five modified braille dots were captured with the program Leica Application Suite. The diameter $(\mathrm{mm})$ and perimeter $(\mathrm{mm})$ were obtained by analysing five captured images of each sample, while the mean values and standard variations were calculated separately for each set of measurements. The surface area $\left(\mathrm{mm}^{2}\right)$ of the dots was calculated from the diameter.

The surface and structure morphology of the samples were studied with a scanning electron microscope (SEM) JSM-6060LV (Jeol, Japan). For the surface observation, the samples were fixed on a specimen stub and the sample cross-sections were prepared using a low-speed diamond saw (Buehler, USA). The samples were than clamped into a special stub for parallel viewing. All the 
samples were covered with an ultra-thin coating of gold (with high-vacuum evaporation). From the cross-section images, the heights $(\mathrm{mm} ; \mu \mathrm{m})$ of the different elements of the braille dots were measured.

\section{RESULTS AND DISCUSSION}

\subsection{Unprinted and pre-printed cardboard properties}

As can be seen from Table 1, the unprinted cardboard had a smooth surface, with a low roughness value and low surface tension due to the calendered coating on the felt side (Figures 2a and $\mathbf{2 b}$ ). The pre-printed layer of black UV ink was applied in the process of braille printing due to the noticed spreading of clear UV ink during the printing of the braille dots. The spreading was also noticed in the research of B. Rotar, ${ }^{17}$ offering an explanation that a thin layer of UV black ink reduced the spreading of clear ink, while the printed dots had better sharpness. As determined by our measurements, the layer of black UV ink pre-printed on the surface increased the surface tension, roughness and capillary rise. The increase of the surface tension reduced the spreading of the clear UV ink on the surface and the braille dots had nearly round boundaries. The layer of black UV ink pre-printed on the cardboard surface, clearly visible in Figure 2, was approximately $15.7 \mu \mathrm{m}$ thick. The grammage of the pre-printed cardboard slightly increased, the resistance to bending increasing in the machine direction (MD) and slightly decreasing in the cross direction (CD).

\subsection{Surface and structure morphology of unmodified and modified braille dots}

The images of the unmodified and modified braille dots captured with the SEM are presented in Figure 3. The edges of each dot were slightly less expressed due to the moderate spreading of the liquid UV ink before curing, as shown in Figure 4a. The upper layer of an unmodified braille dot can be seen as a small circle with a

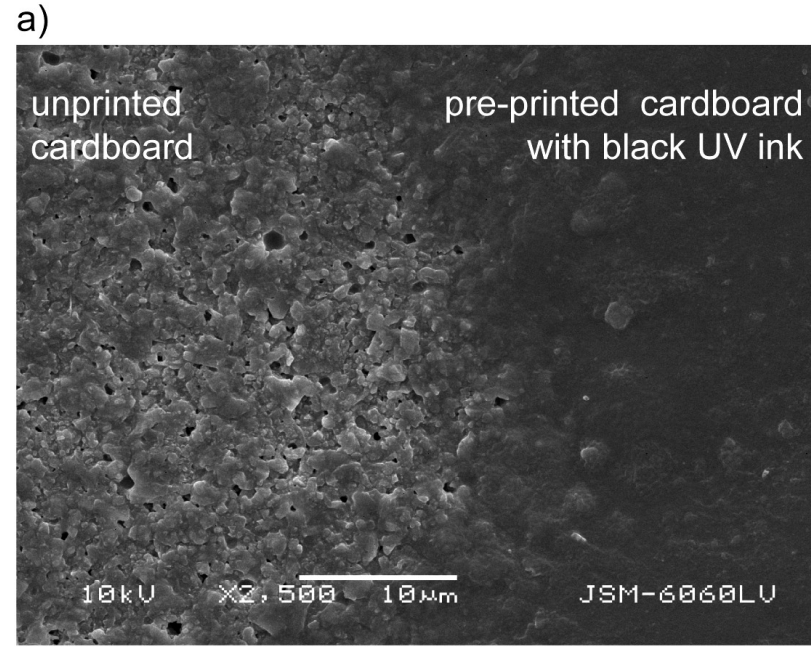

b)

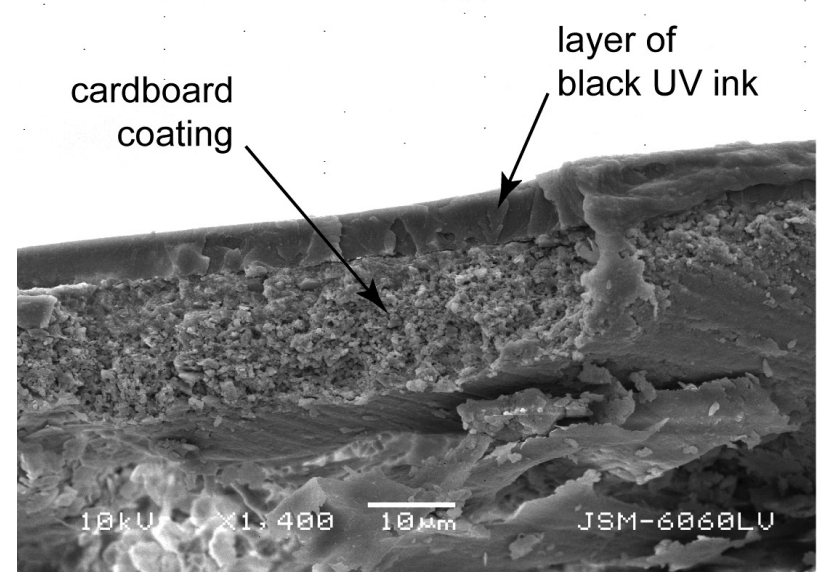

Figure 2: a) Surface of unprinted and pre-printed cardboard with black UV ink, and b) cross section of cardboard pre-printed with UV black ink (mag. a) $2500 \times$ and b) $1400 \times$ )

reduced diameter (Figure 3a). In the cross-section of the unmodified braille dot (Figure 3b), the layer of cured black UV ink is visible. The three applied cured layers of

Table 1: Properties of unprinted and pre-printed cardboard; CV - Coefficient of variation; \% Change - change of measured value of unprinted cardboard against measured value of pre-printed cardboard as percentages

\begin{tabular}{|c|c|c|c|}
\hline Property & Unprinted cardboard & Pre-printed cardboard & $\%$ Change \\
\hline Thickness $(\mu \mathrm{m}) / \mathrm{CV}(\%)$ & $460.30 / 1.17$ & $476.00 / 0.28$ & 3.41 \\
\hline Thickness of UV ink layer $(\mu \mathrm{m})$ & - & 15.7 & - \\
\hline Grammage $\left(\mathrm{g} / \mathrm{m}^{2}\right) / \mathrm{CV}(\%)$ & $274.24 / 0.76$ & $274.56 / 0.99$ & 0.12 \\
\hline $\begin{array}{l}\text { Roughness }(\mathrm{mL} / \mathrm{mm}) / \mathrm{CV}(\%) \\
\text { Side A (felt side) } \\
\text { Side B (wire side) }\end{array}$ & $\begin{array}{l}40.0 / 14.4 \\
359.0 / 8.5\end{array}$ & $\begin{array}{l}138.0 / 6.7 \\
393.0 / 4.9\end{array}$ & $\begin{array}{c}245.00 \\
4.18\end{array}$ \\
\hline $\begin{array}{l}\text { Resistance to bending }(\mathrm{N}) \\
\mathrm{CD} \\
\mathrm{MD}\end{array}$ & $\begin{array}{l}0.1110 \\
0.2418\end{array}$ & $\begin{array}{l}0.1017 \\
0.2685\end{array}$ & $\begin{array}{l}-8.38 \\
11.04 \\
\end{array}$ \\
\hline $\begin{array}{l}\text { Capillary rise }(\mathrm{mm}) / \mathrm{CV}(\%) \\
\mathrm{CD} \\
\mathrm{MD}\end{array}$ & $\begin{array}{l}4.72 / 1.95 \\
3.83 / 2.15\end{array}$ & $\begin{array}{l}4.82 / 2.14 \\
3.99 / 2.92\end{array}$ & $\begin{array}{l}2.12 \\
4.18\end{array}$ \\
\hline Surface tension $\left(\mathrm{mJ} / \mathrm{m}^{2}\right)$ & 34.88 & 46.84 & 34.29 \\
\hline
\end{tabular}



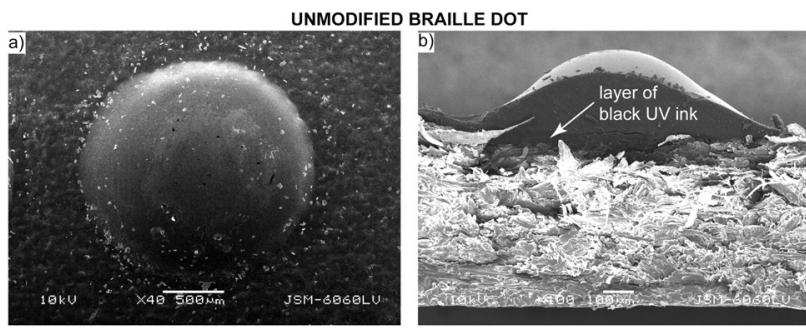

MODIFIED BRAILLE DOT

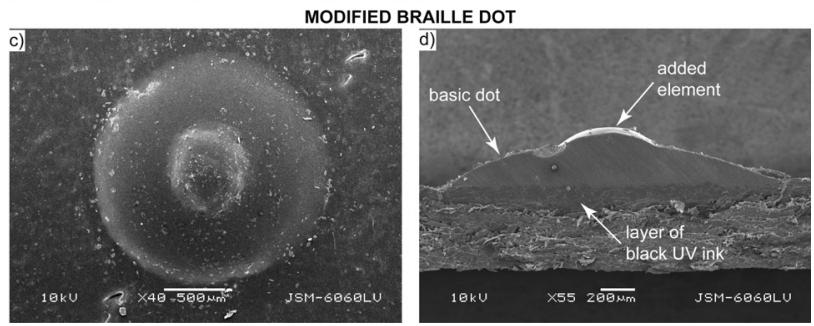

Figure 3: Unmodified and modified braille dot: a) and c) top view, b) and d) cross-section of dots (mag. 40x)

clear UV ink in the braille dot were obviously firmly crosslinked together; thus, no boundary lines representing the intermediate surfaces of the layers applied on each other were noticed. In the modified braille dot, some deviation of the added element from the centre of the basic dot can be noticed (Figure 3c); however, this deviation does not disturb the appearance and tactile experience of the braille dot on the whole. The inner structure of the modified dot was homogeneous (Figure 3d), and the same as in the case of the unmodified dot, the layers of clear UV ink were again firmly crosslinked together without any intermediate boundaries.

The cracking of the cured clear UV ink (Figure 4b) only appeared between the basic dot and the thin, 20-50- $\mu \mathrm{m}$-wide edges, which corresponded to the slight spreading of the UV ink (Figure 4a). According to Mendes-Felipe et al., ${ }^{12}$ some irregularities, e.g., cracking, spreading, could be reduced by optimizing the printing variables. However, in our research, these irregularities were insignificant according to the purpose and we therefore did not focus on a further optimisation of the parameters.

The surface of the pre-printed cardboard and dots was mainly smooth (Figure 5a and Figure 2a); however, by tilting the sample holder during the SEM observations, the deposited small droplets appeared due to the inkjet principle of printing. In inkjet printing, regardless of its technology (e.g., piezoelectric or drop-on-demand), an image is created from an array of extremely small liquid printing-ink droplets printed on various surfaces, either side by side or overlapping. The density of the distribution of the individual droplets depends on the colour shade, saturation and image design (content). These small black and clear UV ink droplets could also be seen on the surface of the pre printed cardboard and the printed braille dots (Figure 5b). They were evenly distributed throughout the surface. Their approximate size, measured from captured SEM images, was $50 \mu \mathrm{m}$.
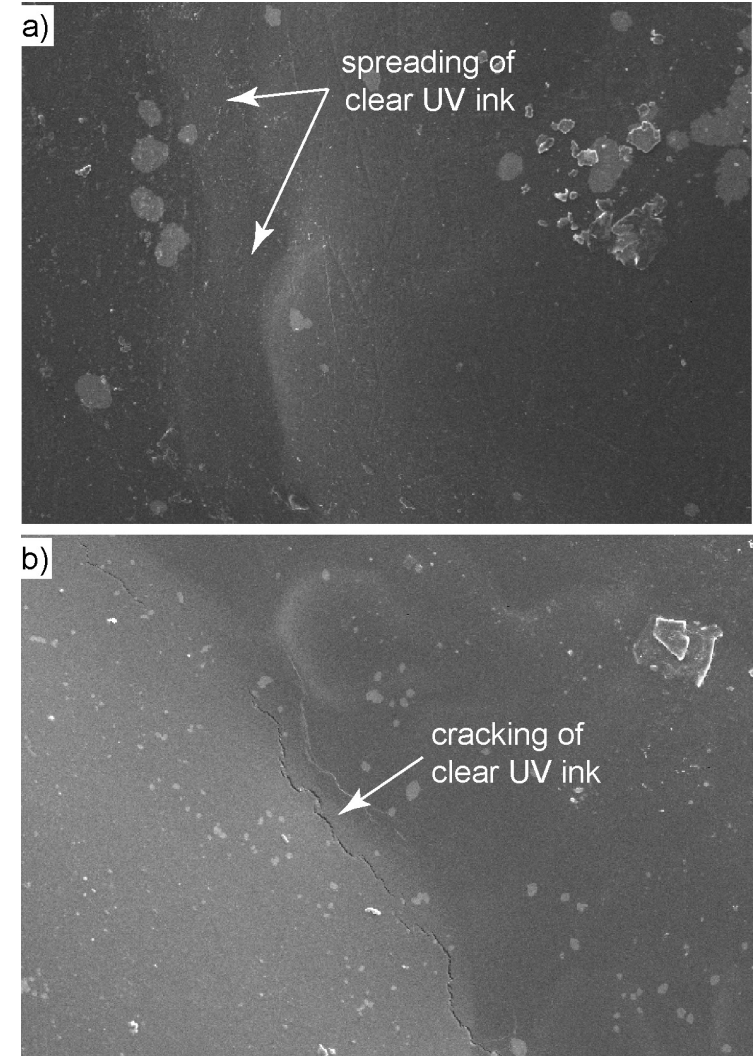

Figure 4: a) Spreading and b) cracking of clear UV ink (mag. a) 170x, b) $220 \times$ )
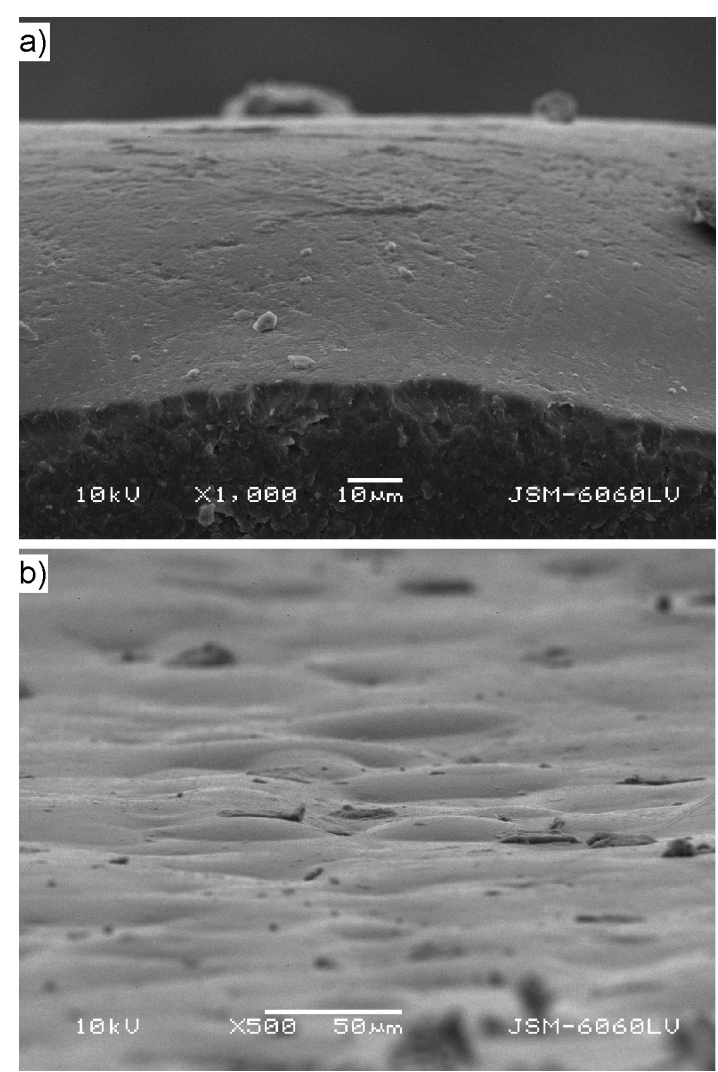

Figure 5: Surface of braille dot: a) smooth, and b) deposited by droplets of clear UV ink (mag. a) $1000 \times$, b) 500x) 
B. ROTAR et al.: MORPHOLOGICAL AND DIMENSIONAL PROPERTIES OF UNMODIFIED AND MODIFIED BRAILLE DOTS ...
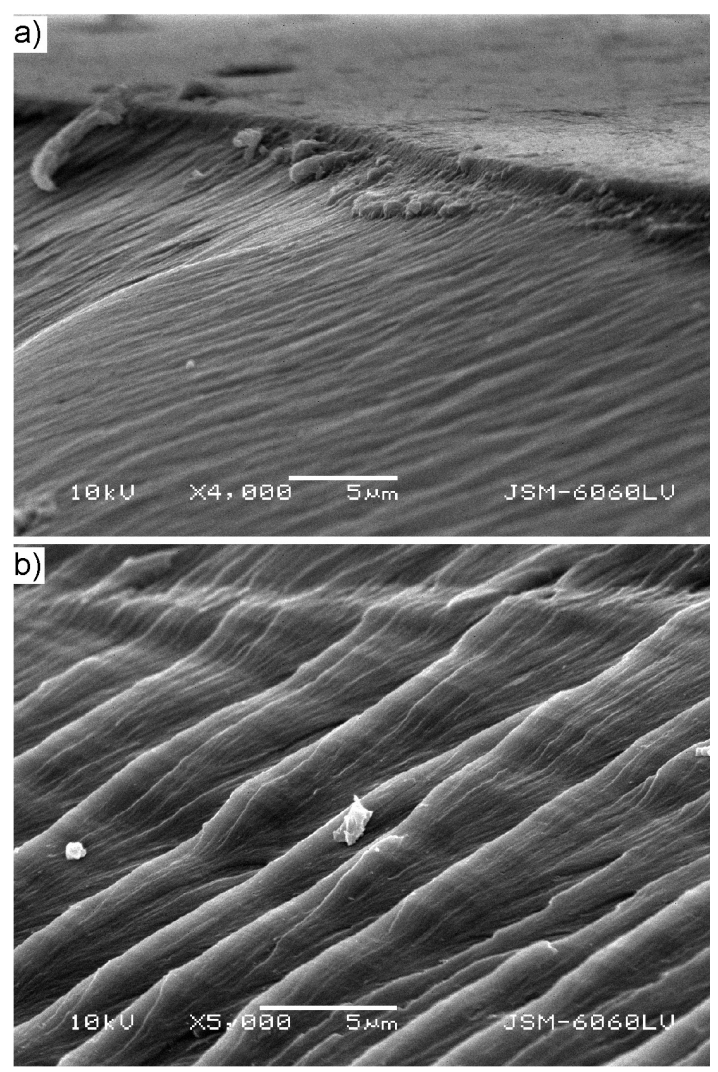

Figure 6: Surface of braille dot fracture (mag. a) $4000 \times$ and b) $5000 \times$ )
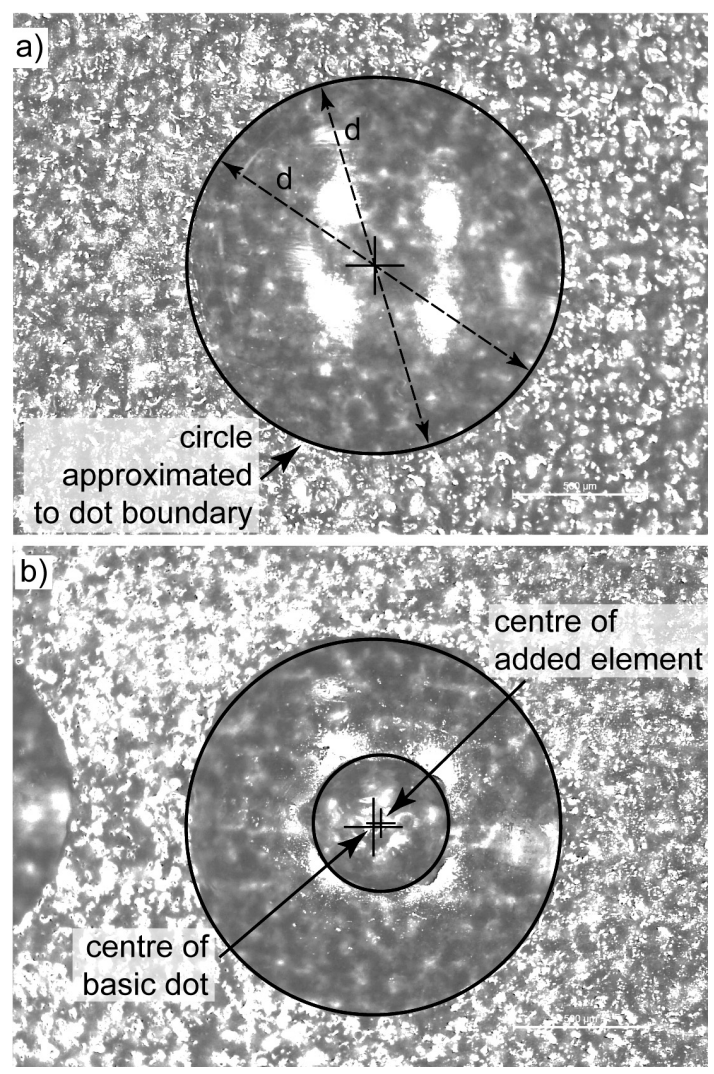

Figure 7: a) Measuring diameter of unmodified braille dot, and b) shifted centres of basic dot and added element of modified dot (original mag. of captured images $40 \times$ )
While preparing the cross-sections of braille dots, some brittle fractures with revealed ridge pattern (waviness) microstructure appeared (Figure 6).

\subsection{Braille dot dimensions}

The images of unmodified and modified braille dots captured with a stereo microscope were analysed with the ImageJ program (Figure 7). For diameter measurements (Figure 7a), the centre of each dot was first determined according to the circle that was approximated to the dot boundary. A set of diameter measurements was performed by measuring the distance from one side to the opposite through a marked centre (d in Figure 7a). The mean values and standard deviations were calculated from the measurements. The diameter of the elements added on the modified dots was measured and calculated in the same way. The centre of the added element did not always exactly overlap with the centre of the basic dot; therefore, for more exact measurements, the centres had to be determined separately (Figure $\mathbf{7 b}$ ).

The area of the dots was calculated from the measured diameter. The perimeter was measured using the ROI (Regions of interest) function in the ImageJ program to obtain the real value of the UV ink spreading extension (Figure 8).

Table 2: Dimensions of unmodified braille dot; mean value \pm SD (standard deviation); $d_{\mathrm{b} 2}$ and $h_{\mathrm{b} 2}$ - diameter and height of printed base dot; \% Change - change of measured dimension compared to preformulated dimension of braille dot from layout as percentages

\begin{tabular}{|c|c|c|}
\hline Property & Mean \pm SD & $\%$ Change \\
\hline Diameter $-d_{\mathrm{b} 2}(\mathrm{~mm})$ & $1.390 \pm 0.027$ & -12.33 \\
\hline Area $\left(\mathrm{mm}^{2}\right)$ & 1.518 & -23.18 \\
\hline Perimeter $_{\mathrm{ROI}}\left(\mathrm{mm}^{2}\right)$ & $6.080 \pm 0.057$ & 22.01 \\
\hline Height $-h_{\mathrm{b}}(\mathrm{mm})$ & $0.193 \pm 0.008$ & - \\
\hline $\begin{array}{l}\text { Thickness of one layer } \\
(\mu \mathrm{m})\end{array}$ & 64.33 & - \\
\hline
\end{tabular}

The height of the unmodified and modified dots was obtained with the SEM, while the approximate thickness of one printed layer was calculated from the height knowing the number of layers in each dot. The results of the measurements for the unmodified and modified dots are presented as mean \pm standard deviation (SD) in Table 2 and Table 3.

As can be seen from Table 2, the diameter of the printed unmodified dot $\left(\mathrm{d}_{\mathrm{b} 2}\right)$ decreased by $12.33 \%\left(\Delta d_{\mathrm{b}}\right.$ for unmodified dot in Figure 9) compared to the pre-formulated diameter of the dot $\left(d_{\mathrm{b} 2}\right.$, which was $\left.1.586 \mathrm{~mm}\right)$. The same was observed for the basic dot of the modified dot (Table 3), where the diameter $\left(d_{\mathrm{b} 2}\right)$ was reduced by $11.41 \%\left(\Delta d_{\mathrm{b}}\right.$ for modified dot in Figure 9). The decrease in area was consequently noticed in both types of dots. The decrease in diameter and area was a result of clear UV ink shrinkage during curing, which is as previously mentioned not an unknown problem arising from the difference in the volume of ink in the liquid and 
Table 3: Dimensions of modified braille dot; mean value \pm SD (standard deviation); $d_{\mathrm{b} 2}$ and $h_{\mathrm{b} 2}-$ diameter and height of printed base dot; $d_{\mathrm{e} 2}$ and $h_{\mathrm{e} 2}$ - diameter and height of printed added element; \% Change - change of measured dimension compared to preformulated dimension of dot from layout as percentages

\begin{tabular}{|l|c|c|c|c|}
\hline \multirow{2}{*}{ Property } & Basic dot & \multicolumn{3}{c|}{ Added element (smaller dot) } \\
\cline { 2 - 5 } & Mean $\pm \mathrm{SD}$ & \% Change & Mean \pm SD & \% Change \\
\hline Diameter $-d_{\mathrm{b} 2} / d_{\mathrm{e} 2}(\mathrm{~mm})$ & $1.405 \pm 0.025$ & -11.41 & $0.528 \pm 0.047$ & 5.51 \\
\hline Area $\left(\mathrm{mm}^{2}\right)$ & 1.550 & -21.56 & 0.218 & 11.46 \\
\hline Perimeter ${ }_{\text {ROI }}\left(\mathrm{mm}^{2}\right)$ & $5.896 \pm 0.017$ & 18.32 & $2.506 \pm 0.025$ & 59.52 \\
\hline Height $-h_{\mathrm{b}} / h_{\mathrm{e}}(\mathrm{mm})$ & $0.152 \pm 0.013$ & - & $0.105 \pm 0.007$ & - \\
\hline Thickness of one layer $(\mu \mathrm{m})$ & 50.66 & - & 35.00 & - \\
\hline
\end{tabular}

cured states (the free volume of three-dimensional polymer structures is smaller than the free volume of molecules (monomers and oligomers) involved). ${ }^{9}$

The perimeter calculated with the ROI function increased by $22.01 \%$ and $18.32 \%$ for the unmodified dot and the basic dot of the modified dot, respectively, according to pre-formulated dimensions of the braille dot. In both cases, the increase was a consequence of slight spreading of the UV ink on the surface before curing. However, slightly different results were obtained for the added element in the modified dot according to preformulated dimensions. The diameter and area increased by $5.51 \%$ and $11.46 \%$, respectively, although the shrinkage of the UV ink was in progress during curing. The perimeter increased significantly, which implies that the added element increased in size. The layers of the added element were not applied on a flat but on a rounded surface of the basic dot (Figure 3), which implies that the jetted drop of liquid UV ink spread slightly down the slope of the basic dot, resulting in an increased diameter, area and especially perimeter in the case of the modified dot.

The difference in height ( $\Delta h$ in Figure 10) between the unmodified dot and the basic dot of the modified dot was $21.1 \%$ (Table 2 and Table 3), although they were both printed simultaneously in the same manner, under the same conditions. a)

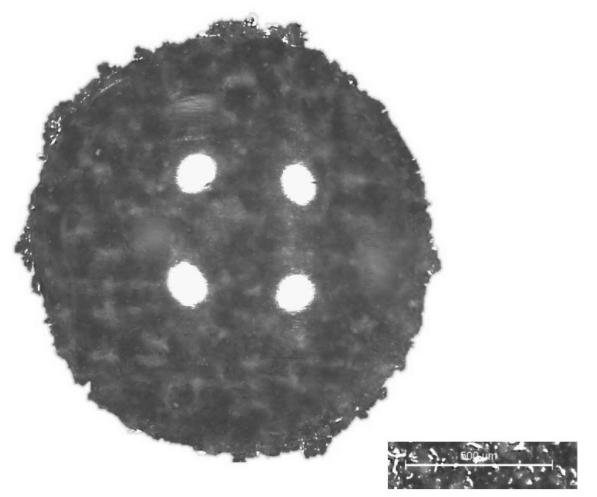

b)

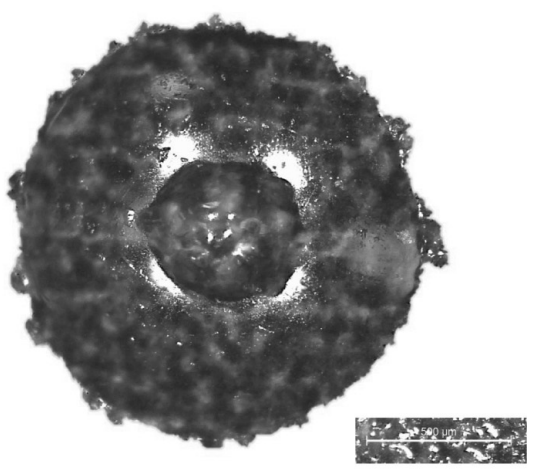

c)

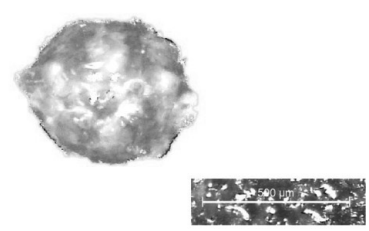

Figure 8: ROI (Regions of interest) of a) unmodified braille dot, b) modified dot, and c) added element (original mag. of captured images $40 \times$ )

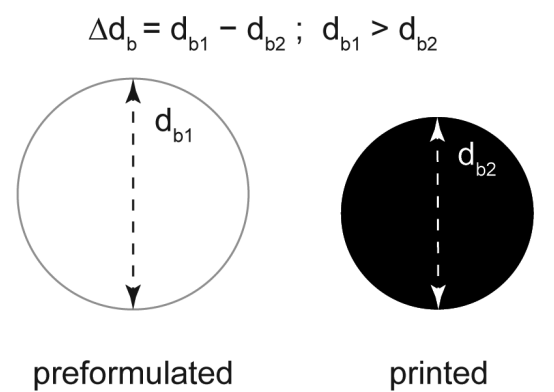

UNMODIFIED DOT

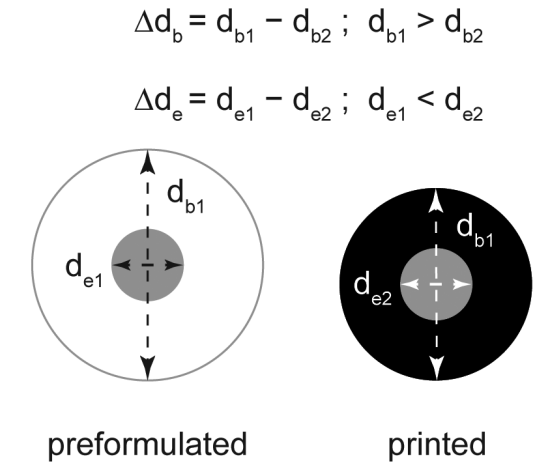

\section{MODIFIED DOT}

Figure 9: Diameters of preformulated and printed unmodified and modified dots; $d_{\mathrm{b} 1}-$ diameter of preformulated base dot; $d_{\mathrm{b} 2}-\mathrm{diameter}_{\mathrm{a}}$ printed base dot; $d_{\mathrm{e} 1}$ - diameter of preformulated added element; $d_{\mathrm{e} 2}$ - diameter of printed added element 


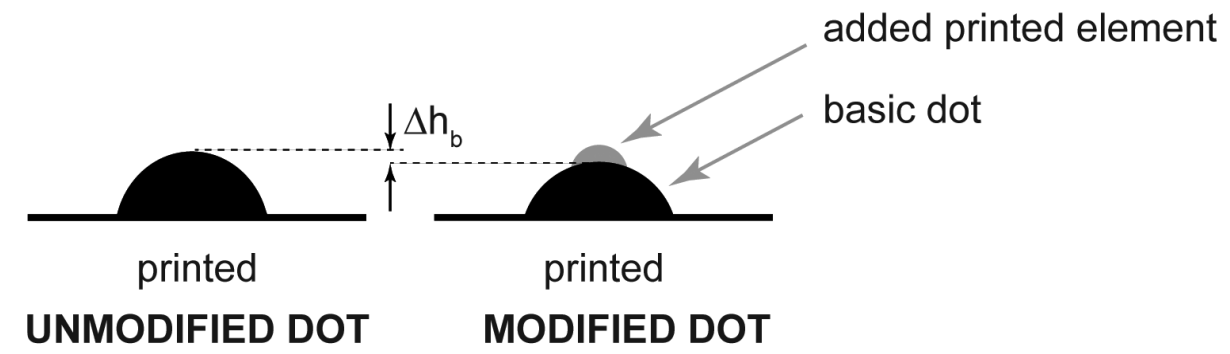

Figure 10: Difference in heights of the base dots of the unmodified and modified dots

Apart from shrinkage, which can influence the height of the dot, a tiny "collapse" of slightly less crosslinked layers or parts (especially the centre) of the dot could be possible under the weight of the added element. Decker ${ }^{18}$ stated in his research that the ratio between the cure speed and the cure depth must be taken into consideration during the polymerisation. He also concluded that an increase in the light intensity leads to a faster polymerisation and more extensive cure with a smaller number of unreacted functional groups. In our study, the curing of UV ink was performed at the same light intensity. It is possible that in the first (lower) layers of the dot (especially in the case of the modified dot) some uncured UV ink was still present, forming "softer" areas that could collapse during the printing and reduce the heights of the unmodified dot. Another explanation relates to the colour of the substrate, which can influence the curing speed. Brunner ${ }^{19}$ discovered that dark substrates, especially black, require more energy for curing the UV ink layer than the bright ones. In our research, the curing of each layer of dots was conducted under the same conditions and it is thus possible that the layer of the dot, which was printed directly onto a black coloured surface, was slightly less crosslinked than the other two layers. Such a layer is more susceptible to deformation as well as collapse, consequently resulting in a reduced height of the basic dot.

\section{CONCLUSIONS}

UV inkjet printing is a suitable technique for printing braille. It enables the production of clear and precise prints, which is an important issue in printing modified braille dots, as presented in our research. According to the results, unmodified and modified braille dots printed with clear acrylate-based UV ink had a smooth tactile surface and were suitably shaped as preformulated by the layout. All the printed dots had a ridge-pattern formed microstructure, which applies to the amorphous polymer. Although slight spreading and cracking of the clear UV ink was observed, this should not affect the visual and tactile experience of the visually impaired and the blind as it was confirmed by the study ${ }^{16}$ in which printed unmodified and modified braille with a group of blind people was performed. According to the results, when preparing layouts for inkjet printing, shrinkage during UV curing should be considered.
Although the shrinkage was determined with measurements, the dimensions of the printed unmodified and modified dots were still within the acceptable range according to the Marburg Medium Standard, i.e., the diameter of the dot being in the range 1.3-1.6 mm. The Marburg Medium Standard does not specify the braille dot height, but the height target of $0.20 \mathrm{~mm}$ is, e.g., recommended for pharmaceutical packaging. In our research, the unmodified dot was within the proposed dimensions; however, the modified dot was higher by almost $30 \%$ due to the added printed element. The modified dot was intentionally higher, as it indicated a capital letter.

The dimensional changes of the unmodified and modified braille dots established by measurements originate from different causes, such as UV ink spreading, the shrinkage of printed dots during curing, a small percentage of uncured ink, a black surface of the substrate, etc. Some of the mentioned reasons are assumptions based on the literature cited; nevertheless, they are a good starting point for further research.

\section{Acknowledgment}

The authors acknowledge Grec d. o. o. Grafično ekološki center, Poclain Hydraulics d. o. o., Tiskarna Novo mesto, Department of Materials and Metallurgy, University of Ljubljana, and the Pulp and Paper Institute for technical support.

\section{REFERENCES}

\footnotetext{
${ }^{1}$ C. Simpson, The Rules of Unified English Braille, $2^{\text {nd }}$ ed., International Council on English Braille, Lindisfarne 2013, 344

${ }^{2}$ E. Kibirkštis, I. Venytė, V. Mayik, D. Vakulich, Investigation of geometrical and physical - mechanical parameters of Braille by assessing the different types of cardboard materials, Mech., 17 (2011) 6, 656-660, doi:10.5755/j01.mech.17.6.1010

${ }^{3}$ V. Mayik, T. Dudok, E. Kibirkštis, I. Venyte, Research of Durability of Braille Formed in Paper. Mech., 25 (2019) 1, 82-86, doi:10.5755/j01.mech.25.1.20985

${ }^{4}$ S. Havenko, V. Kochubei, M. Labetska, S. Khadzhynova, E. Kibirkštis, I. Venite, Thermal Analysis of Braille Formed by Using Screen printing and Inks with Thermo Powder, Mater. Sci-Medzg., 21 (2015) 1, 52-56, doi:10.5755/j01.ms.21.1.5702

${ }^{5}$ U. Stankovič Elesini, M. Pivar, P. Anžel, A. Kermauner, R. Urbas, Prilagoditev muzejskih poti slepim in slabovidnim, Študija procesov, tehnologij in materialov v razvoju prilagoditve, 1st ed., Univerza v Ljubljani in Mestna občina Ljubljana, Ljubljana 2019, 83-140
} 


\section{B. ROTAR et al.: MORPHOLOGICAL AND DIMENSIONAL PROPERTIES OF UNMODIFIED AND MODIFIED BRAILLE DOTS ...}

${ }^{6}$ A. Agić, L. Mandić, H. Gabrijelčič Tomc, An innovative Braille alphabet teaching tool for visually impaired individuals based on advanced tactile embossed 3D graphics, Acta Graphica, 29 (2018) 1, 7-14, doi:10.25027/agj2017.28.v29i1.144

${ }^{7}$ M. Sangermano, D. Foix, G. Kortaberria, M. Messori, Multifunctional antistatic and scratch resistant UV-cured acrylic coatings, Prog. Org. Coat., 76 (2013), 1191-1196, doi:10.1016/ j.porgcoat.2013.03.030

${ }^{8}$ X. Wang, B. Wang, W. Xing, G. Tang, J. Zhan, W. Yang, L. Song, Y. $\mathrm{Hu}$, Flame retardancy and thermal property of novel UV-curable epoxy acrylate coatings modified by melamine-based hyperbranched polyphosphonate acrylate, Prog. Org. Coat., 77 (2014) 1, 94-100, doi:10.1016/j.porgcoat.2013.08.010

${ }^{9}$ J. W. Park, G. S. Shim, J. G. Lee, S. W. Jang, H. J. Kim, J. N. Choi, J.N., Evaluation of UV Curing Properties of Mixture Systems with Differently Sized Monomers, Mater., 11 (2018) 509, 1-14, doi: $10.3390 / \mathrm{ma} 11040509$

${ }^{10}$ M. Sangermano, A. Chiolerio, G. Marti, P. Martino, UV-Cured Acrylic Conductive Inks for Microelectronic Devices, Macromol. Mater. Eng., 298 (2013) 607-611, doi:10.1002/mame.201200072

${ }^{11}$ X. Yang, X. Wei, B. Huang, W. Zhang, I. Zhao, Study on the Printability of UV-Curable Inkjet Ink on Different Printed Materials, App. Mech. Mat., 262 (2013) 324-328, doi:10.4028/www.scientific.net/AMM.262.324
${ }^{12}$ C. Mendes-Felipe, J. Oliveira, I. Etxebarria, J. L. Vilas-Vilela, State-of-the-Art and Future Challenges of UV Curable Polymer-Based Smart Materials for Printing Technologies, Adv. Mater. Technol., 4 (2019) 1-16, doi:10.1002/admt.201800618

${ }^{13}$ J. W. Park, G. S. Shim, J. H. Back, H. J. Kim, S. Shin, Characteristic shrinkage evaluation of photocurable materials, Polym. Test., 56 (2016) 344-353, doi:10.1016/j.polymertesting.2016.10.018

${ }^{14}$ K. Koseki, H. Sakamaki, K. M. Jeong, In situ Measurement of Shrinkage Behavior of Photopolymers, J. Photopolym. Sci. Tech., 26(4) (2013) 567-572, doi:10.2494/photopolymer.26.567

${ }^{15}$ G. Golob, D. Gregor Svetec, R. Urbas, B. Rotar, N. Jereb, V. Mayik, T. Dudok, Dot shape and legibility analysis of multilayer UV ink-jet printed Braille text, XI ${ }^{\text {th }}$ Symp. on Graphic Arts, Pardubice, 2013, 61-67

${ }^{16}$ R. Urbas, B. Rotar, P. Hajdu, U. Stankovič Elesini, Evaluation of the modified braille dots printed with the UV ink-jet technique, JGED, 2 (2016) 15-24, doi:10.24867/JGED-2016-2-015

${ }^{17}$ B. Rotar, Cardboard packaging with Braille. University of Ljubljana, Faculty of Natural Sciences and Engineering, Ljubljana 2013, 99

${ }^{18} \mathrm{C}$. Deker, The Use of UV Irradiation in Polymerization, Polym. Int., 45 (1998) 133-141, doi:10.1002/(SICI) 1097-0126(199802)45:2 $<133:$ :AID-PI969>3.0.CO;2-F

${ }^{19}$ A. Brunner, Reactivity of UV-curing screen ink system, Screen News, 2008, 4-5 